\title{
Pengaruh Likuiditas Terhadap Kinerja Perusahaan Pada Perusahaan Yang Terdaftar Di BEI
}

\author{
Nabilla Octaviana Dirmansyah ${ }^{1}$, Lala Syalsabila ${ }^{2}$, dan Henny Setyo Lestari ${ }^{3}$ \\ ${ }^{1,2,3}$ Faculty of Economics and Business, Trisakti University Jakarta \\ Email address: \\ nabillaoctaviana@gmail.com: Syalsabilala@gmail.com: henny_setyo_lestari@trisakti.ac.id
}

\begin{abstract}
The purpose of this research is to conclude the impact of liquidity on firm peformace. The sample in this study are companies from food and beverages subsector listed on Indonesia Stock Exchange in 2016-2020. The sampling technique used in this study is purposive sampling and the analysis method is panel data regression. The independent variables in this study are acid ratio and current ratio, and the control variable is sales growth and firm size, with the firm performance as the dependent variable. The results show that Acid ratio has insignificant effect on ROA and ROE, Current Ratio has insignificant effect on ROA and has a negative and significant effect on ROE. Sales growth has a positive and significant effect on ROA and has an insignificant effect on ROE. Firm size has a positive and significant effect on ROA and ROE.
\end{abstract}

Keywords: Acid Ratio, Current Ratio, Sales Growth, Firm Size, Firm Peformance.

Abstrak: Penelitian ini tujuannya agar dapat melihat pengaruh dari likuiditas terhadap kinerja perusahaan. Penggunaan sampel penelitian yang digunakan yaitu perusahaan subsektor makanan dan minuman yang tercatat di BEI selama pengamatan 2016-2020 yang jumlahnya 35 perusahaan. Teknik untuk pengambilan sampel penelitiannya ialah purposive sampling serta metode analisa regresi data panel. Variabel bebas yang diplih oleh peneliti yakni acid ratio dan current ratio serta variabel kontrol yakni sales growth dan firm size dengan kinerja perusahaan sebagi variabel dependen. Hasilnya membuktikan bahwa Acid ratio memberi pengaruh tidak signifikan terhadap ROA dan ROE, Current Ratio mempengaruhi ROA tidak signifikan serta memiliki signifikan negatif pada ROE. Sales growth memberi pengaruh signifikan positif terhadap ROA serta berpengaruh terhadap ROE tidak signifikan. Firm size memberi pengaruh signifikan positif terhadap ROA dan ROE.

Kata Kunci: Acid Ratio, Current Ratio, Sales Growth, Firm Size, Kinerja Perusahaan.

\section{PENDAHULUAN}

Perusahaan merupakan sebuah organisasi yang kegiatannya meliputi produksi dan distribusi untuk mencukupi kebutuhan manusia (Nurdiana, 2018). Peran perusahaan yang berada di suatu negara termasuk Indonesia salah satunya adalah untuk meningkatkan 
perekonomian. Terjadinya pandemi Covid-19 secara global membuat perekonomian berbagai negara menurun tak terkecuali Indonesia. Merujuk data yang diolah oleh BPS, perekonomian di Indonesia di tahun 2020 pada TWI tumbuh sebesar 2,97\% namun setelah itu pada TWII,TWII dan TWIII mengalami kontraksi sebesar $-5,32 \%$ (yoy), $-3,49 \%$ dan $2,19 \%$ secara berturut-turut. Indonesia telah sebagai negara yang berbasis industri manufaktur paling besar se-Asean yang mempunyai kontribusi hingga pencapaian 20,27\% dari perekonomian nasional (www.investindonesia.go.id). Perusahaan manufaktur di Indonesia tersendiri termasuk beberapa kategori subsektor. Banyaknya perusahaan manufaktur yang tercatat di BEI hingga 2021 berjumlah 193 perusahaan.

Perusahaan manufaktur yang kian banyak dan daya saing yang memadai membuat pelaku usaha dalam industri ini mengalami persaingan yang ketat. Oleh karena itu untuk menghadapi persaingan yang kompetitif, setiap perusahaan berusaha untuk mengoptimalisasi tingkat kinerjanya (Priatna dan Yuliani, 2018). Walaupun pada saat pandemi industri manufaktur terpukul cukup telak namun masih ada beberapa subsektor manufaktur yang mencatatkan kinerja positif pada kuartal IV 2020. Salah satu subsektor yang mencatatkan kinerja positif adalah subsektor makanan dan minuman dengan pertumbuhan sebesar 1,66\% dikarenakan permintaan yang cukup tinggi sebab masyarakat yang butuh akan konsumsi asupan berkualitas dalam menjaga kesehatannya (www.kemenperin.go.id). Data yang di dapat dari Warta Ekonomi menyatakan bahwa pada triwulan III tahun 2020 saja industri makanan dan minuman menyumbang besaran PDB nasional hingga mencapai 7,02\% dan industri makanan mengeluarkan investasi sebesar Rp 40,53 triliun rupiah pada Januari-September 2020.

Setiap aktivitas yang dimiliki oleh perusahaan dilakukan untuk mencapai suatu tujuan, yakni menghasilkan laba. Salah satu keberhasilan perusahaan dalam mencapai tujuannya dapat dilihat dengan cara menilai kinerja perusahaan tersebut. Kinerja perusahaan adalah suatu hasil dari kegiatan yang dilaksanakan perusahaan yang menjadi parameter dari kesuksesan perusahaan (Apriliani dan Dewayanto, 2018). Ada sejumlah rasio keuangan yang bisa dimanfaatkan dalam melihat seberapa baik kinerja perusahaan dan apakah sumber daya perusahaan dikelola secara efektif. Termasuk diantaranya rasio profitabilitas. Rasio profitabilitas memperlihatkan keberhasilan manajemen perusahaan serta memberikan informasi tata kelola perusahaan tentang kinerja departemen perusahaan (Şamíloğlu et al., 2017). Hasil riset dari (Sundas dan Butt, 2021) memanfaatkan ROA dan ROE sebagai pengukuran kinerja suatu perusahaan. ROA menggambarkan bagaimana manajemen sebuah perusahaan menggunakan aset ataupun sumber daya yang mereka punya untuk menciptakan laba, sementara ROE ialah rasio yang menggambarkan sebanyak apa laba yang diciptakan oleh perusahaan sebagai persentase dari ekuitas pemegang saham (Şamİloğlu, Öztop dan Kahraman, 2017).

Keuntungan perusahaan dapat dinilai dari besar atau kecilnya penjualan perusahaan dari sebuah periode ke periode selanjutnya. Kegiatan perusahaan dalam memantau sales growth ini dapat dikatakan sebagai upaya dalam meningkatkan kinerja perusahaan dikarenakan perusahaan harus memahami tumbuh kembang kegiatan bisnisnya dari setiap tahunnya (Fibianti dan Utiyati, 2020). Setelah melakukan evaluasi ataupun pemantauan terhadap sales growth maka perusahaan dapat menilai apakah sales growth mereka dari satu periode ke periode lainnya baik atau buruk. Pertumbuhan perusahaan dalam sales growth 
mempunyai hubungan positif dengan kinerja perusahaan (Samo dan Murad, 2019) karena perusahaan yang mempunyai output penjualan yang nilainya tinggi akan memberi pengaruh yang signifikan terhadap pendapatan perusahaan sehingga memiliki lebih banyak dana untuk ekspansi. Penelitian ini selaras akan hasil riset dari (Sundas dan Butt, 2021) yang mengungkapkan bahwa ada pengaruh signifikan positif antara sales growth dengan kinerja perusahaan. Untuk menentukan besaran firm size ditetapkan berdasarkan total penjualan dan total aktif (Wahyu dan Triyani, 2020). Apabila semakin banyak total aktiva yang dipunyai perusahaan sehingga bertambah besar juga modal yang akan ditanamkan dan akan bertambah besar pula peputaran uang di perusahaan yang dapat menyebakan meningkatnya kinerja keuangan. Baiknya akses pasar pasti mempunyai kegiatan operasional yang luas maka perusahaan besar memiliki peluang untuk memperoleh laba lebih tinggi yang bisa menaikan kinerja perusahaan (Patricia, 2018). Dikarenakan sales growth dan firm size sangat penting saat mengevaluasi kinerja perusahaan, pengaruhnya juga akan dipelajari di dalam penelitian ini.

Manajemen likuiditas sangat penting bagi setiap perusahaan untuk memenuhi kewajiban pembayaran yang mencakup biaya operasional dan keuangan jangka pendek yang dapat menyebabkan hutang di masa depan (Sundas dan Butt, 2021). Oleh karena itu, likuiditas bisa disebut sebagai alat pengukur untuk mengevaluasi kinerja perusahaan untuk membayar hutang jangka pendeknya. Mengelola likuiditas secara efektif dapat membantu perusahaan dalam mengatasi risiko ketidakmampuan perusahaan untuk membayar kewajibannya saat jatuh tempo, di sisi lain pengelolaan ini membuat perusahaan terhindar dari pengeluaran yang berlebihan dari aset yang dipunyai oleh perusahaan. Perusahaan harus mengerti cara mengatur keuangannya untuk mempertahankan jumlah aset lancar yang akan digunakan untuk memastikan bahwa perusahan telah memenuhi kebutuhan operasional tertentu dan membayar kewajibannya pada tanggal yang telah ditentukan (Shakatreh, 2021).

Menurut (Yameen et al., 2019) mengelola tingkat likuiditas yang efisien dapat menghindari perusahaan dari kegiatan berinvestasi secara berlebihan dari aset yang dimilikinya. Menyeimbangkan tingkat likuiditas perusahaan dan memaksimalkan laba sangat penting karena banyak perusahaan yang pada akhirnya kehilangan kesempatan dalam memperoleh tingkat kinerja yang baik dalam memperoleh laba yang diakibatkan oleh perusahaan yang secara terus-menerus mempertahankan tingkat likuiditas yang tinggi (Shakatreh, 2021). Apabila perusahaan hanya memperhatikan tingkat likuiditas dan tidak memperhatikan kinerjanya dalam menghasilkan laba maka mereka akan menghadapi masalah yang berhubungan dengan pertumbuhan dan kemajuan perusahaannya. Oleh karena itu, likuiditas dianggap penting oleh perusahaan dikarenakan sebagai salah satu faktor yang memberi pengaruh tingkat profitabilitas yang digunakan untuk mengukur kinerja perusahaan (Yameen et al, 2019).

Penelitian yang dilaksanakan oleh (Sundas dan Butt, 2021) menggunakan current ratio dan acid ratio sebagai alat yang dipakai sebagai pengukuran tingkat likuiditas perusahaan. Current ratio dan acid ratio dianggap sebagai alat yang biasanya dipakai dalam pengukuran likuiditas perusahaan (Yameen et al, 2019). $C R$ dihitung melalui cara memperbandingkan antara hutang jangka pendek dengan kewajiban jangka pendek. Ketika current ratio tinggi dapat diartikan bahwa potensi perusahaan dalam melunasi kembali 
hutang jangka pendeknya baik. Sedangkan acid ratio adalah rasio yang digunakan untuk memperlihatkan aktiva lancar yang paling likuid untuk melunasi kewajiban jangka pendek, karena memperbandingkan aktiva lancar yang dikurangi persediaan dengan jumlah hutang jangka pendek (Insan dan Purnama, 2020).

Hasil penelitian yang dilaksanakan oleh (Prijatno et al., 2017) memperlihatkan bahwa ada hubungan signifikan antara current ratio dengan kinerja perusahaan. Penelitian tersebut selaras akan hasil riset dari (Yameen et al., 2019) membuktikan bahwa current ratio memberi pengaruh signifikan positif pada kinerja perusahaan. Penelitian yang sudah dijabarkan tersebut sesuai dengan temuan yang dilaksanakan oleh (Sundas dan Butt, 2021) menjelaskan bahwa current ratio memberi pengaruh signifikan positif pada kinerja perusahaan, akan tetapi acid ratio tidak mempengaruhi kinerja perusahaan. Hal ini tidak sesuai dengan hasil riset dari (Yameen et al., 2019) yang mengungkapkan bahwa ada pengaruh signifikan positif antara acid ratio dengan kinerja perusahaan. (Olawale et al., 2017) menyatakan bahwa acid ratio tidak mempengaruhi kinerja perusahaan.

\section{KAJIAN TEORI}

Kinerja Perusahaan. Kinerja perusahaan adalah kategori ekonomi yang mencerminkan potensi perusahaan untuk menggunakan sumber daya dan kekayaannya untuk mencapai tujuan perusahaan (Nguyen et al., 2021). Sebuah perusahaan dapat dinyatakan mempunyai tingkat kinerja yang baik jika perusahaan tersebut dapat melakukan manajemen perencanaan dan upaya pencapaian tujuan dengan baik yang nantinya akan berpengaruh pada profitabilitas perusahaan sehingga perusahaan dapat dikatakan berhasil dalam manajemen kinerja. Profitabilitas merupakan pengukuran kinerja perusahaan yang signifikan karena pertumbuhan perusahaaan tidak mungkin dapat dipertahankan tanpa adanya ketersediaan pendapatan untuk diinvestasikan kembali (Sundas dan Butt, 2021). Profitabilitas dapat diukur dan diamati dengan cara membandingkan biaya dan aset yang menunjukkan seberapa baik bisnis dalam menggunakan hal yang sama untuk mengembangkan penjualannya (Samo dan Murad, 2019). Rasio profitabilitas menunjukan suatu kombinasi atas pengaruh manajemen aset, likuioditas, serta hutang pada hasil dari operasi perusahaan (Heryanto, 2018).

Rasio profitabilitas yang sering banyak dipakai sebagai pengukuran kinerja perusahaan adalah return on equity (ROE), return on asset (ROA), return on capital employed (ROCE), gross profit margins (GPM), serta net operating margin (NOM) (Samo dan Murad, 2019). Temuan dari (Sundas dan Butt, 2021) memanfaatkan ROA dan ROE sebagai alat pengukur kinerja perusahaan. ROA merupakan rasio yang menjelaskan aset yang dievaluasi berdasarkan penjualan. Untuk keberhasilan pertumbuhan perusahaan, rasio ini harus besar. Kian tingginya ROA sehingga bertambah besar laba yang dihasilkan oleh perusahaan dengan demikian investor akan membeli lebih banyak saham (Alawi, 2019). Sedangkan ROE digunakan untuk menguji komponen ekuitas dari keseluruhan investasi perusahaan. Hasil ROE yang rendah menunjukan kinerja manajemen perusahaan yang tidak efisien. Bertambah tinggi keuntungan yang diciptakan sehingga perusahaan akan memiliki tingginya return on equity sehingga mendongkrak harga saham perusahaam yang menarik perhatian investor. 
Sales Growth. Sales growth adalah indeks kinerja yang memperlihatkan daya saing pada suatu industri dan pasar, perusahaan memiliki tujuan untuk meningkatkan nilai dan kemampuan perusahaan untuk memenuhi kegiatan kinerja dan aktivitas perusahaan, sales growth membantu perusahaan dalam menentukan strategi perusahaan (Fávero et al., 2018). Perusahan perlu merancang strategi dalam memilih aktivitas yang akan dilaksanakan untuk menaikan penjualan dengan melakukan inovasi produk, penetapan harga produk, konsep desain, dan konsep pemasaran pada produk. Sales growth juga berpengaruh pada tingkat keputusan investasi dimana kian tingginya nilai penjualan sehingga bertambah banyak profit yang di dapatkan perusahaan maka perusahaan akan terus mendapatkan pendanaan dari investor, semakin besar dana yang di tanamkan maka investor semangkin besar mendapatkan keuntungan.

Hasil riset dari (Sundas dan Butt, 2021) menemukan bahwa terdapat pengaruh positif signifikan antara sales growth dengan ROA. Dalam penelitian yang dilaksanakan (Muunda, 2019) menemukan bahwa pertumbuhan penjualan memberi pengaruh positif signifikan terhadap ROA dan ROE. Hal ini dikarenakan peningkatan penjualan pada perusahan dinilai dapat meningkatkan kinerja perusahaan. Sementara merujuk pada pandangan (Hasanah dan Enggariyanto, 2018) yang mengungkapkan bahwa sales growth memberi pengaruh positif signifikan pada ROA. Sales growth membuktikan kinerja perusahan yang baik, sehingga penjualan pada periode berikutnya akan memiliki hasil lebih besar maka akan semakin besar profit yang didapatkan. Sebaliknya menurut penelitian dari (Sukadana dan Triaryati, 2018) bahwa sales growth tidak memiliki pengaruh terhadap ROA. Hal ini dikarenakan sales growth dapat menunjukkan adanya kenaikan market share yang dapat berpengaruh terhadap kenaikan penjualan, tetapi pada hasil penelitian yang dilakukan menunjukan bahwa peningkatan penjualan dalam keadaan yang tidak stabil dan mempengaruhi nilai profitabilitas serta mengurangi nilai kepercayaan investor dalam memberikan modal kepada perusahaan. Menurut penelitian yang dilakukan oleh (Ashry dan Fitra, 2019) terdapat pengaruh positif signifikan sales growth terhadap ROE. Pengaruh positif terjadi karena semakin besar sales growth maka perusahaan menunjukan kemampuan dalam menghasilkan profit yang semakin besar yang digunakan untuk pengembalian ekuitas investor.

Firm Size. Firm size adalah skala yang dapat menentukan besar atau kecilnya sebuah perusahaan dari penjualan yang dihasilkan oleh perusahaan. Firm size yang semakin besar dapat membuktikan bahwa perusahaan sedang mengalami peningkatan dalam bisnisnya sehingga investor yang menginvestasikan modalnya kepada perusahaan tersebut memberikan respon positif karena pengembalian modal yang diberikan kepada investor dapat meningkat apabila keuntungan yang didapatkan perusahaan dari penjualan meningkat. Semakin besar firm size maka semakin besar peluang perusahaan untuk mendapatkan sumber modal dari investor (Hirdinis, 2019). Keputusan investor dapat membuat nilai perusahaan semakin besar sehingga profitabilitas perusahaan akan meningkat. Firm size mempengaruhi persediaan dan keuangan dari bisnis yang dikembangkan, perusahaan yang memiliki ukuran yang besar cenderung berhasil dengan melakukan diversifikasi produk, sedangkan perusahaan menengah biasanya berhasil ketika perusahaan tersebut memimpin inovasi dan menjadikan mereka pemasok (Fernández dan Olaso, 2018). Suatu produk atau 
tren yang baru dan terkenal di lingkungan masyarakat akan membuat perusahaan mempengaruhi inovasi terhadap produknya dengan mengikuti pasar yang menjadi keinginan konsumen.

Acid Ratio. Acid ratio adalah suatu standar keuangan yang bisa berguna sebagai pengukuran likuiditas perusahaan dan pusat investasi. Likuiditas ialah indikator potensi perusahaan untuk menuaikan seluruh kewajiban hutang jangka pendek ketika jatuh tempo. Pemenuhan kewajiban jangka pendek menggunakan tangible asset dan sebagian perusahaan hanya dapat menggunakan rasio ini dalam waktu tiga bulan saja, untuk perhitungan jangka panjang biasanya perusahaan lebih memilih menggunakan current ratio (Jurnal dan Mea, 2021). Pada dasarnya acid ratio memiliki kemiripan dengan current ratio. Namun demikian, acid ratio diukur dari melakukan pengurangan nilai persediaan aktiva lancar. Persediaan tidak dapat dimasukkan ke dalam hitungan acid ratio dikarenakan persediaan mempunyai tingkat likuiditas yang beresiko sehingga dapat menimbulkan permasalahan. Selain persediaan termasuk dalam aktiva lancar tidak likuid dan mengurangi nilainya pada saat perusahaan dianyarakan berhenti beroperasi.

Pada penelitian yang dilakukan oleh (Baktiar dan Azhar, 2019) menyatakan bahwa acid ratio berpengaruh positif signifikan terhadap ROA. Hal tersebut membuktikan bahwa kapasitas perusahaan dalam memenuhi hutang jangka pendek bisa diketahui dari aset lancar perusahaan yang kian meningkat sehingga hal ini berpengaruh pada potensi perusahaan untuk mendapatkan keuntungan ketika perusahaan sudahmenunaikan utang jangka pendeknya. Penelitian yang dilakukan (Kusjono dan Rohman, 2020) menyatakan bahwa acid ratio memberi pengaruh positif signfikan terhadap ROE. Sebuah perusahaan harus menjaga tingkat likuiditas dalam kondisi yang optimal. Hal ini dikarenakan jika tingkat likuiditas perusahaan dikelola secara optimal maka perusahaan dianggap dapat menciptakan keuntungan secara efektif dikarenakan perusahaan menggunakan aset perusahaannya bukan hanya untuk membayar kewajiban jangka pendeknya saja namun untuk diputarkan kembali terhadap investasi yang dapat menciptakan keuntungan bagi perusahaan serta mendapat kepercayaan dari investor dalam memberikan modal di perusahaan. Terjadinya perubahan pada aktiva lancar bisa mempengaruhi peningkatan profit karena ketersediaan dana yang dimiliki perusahaan dinilai juga kian meningkat untuk menghasilkan keuntungan dan dapat diartikan bahwa tingkat likuiditas perusahaan akan semakin meningkat, sehingga likuiditas bisa mempengaruhi keuntungan yang akan dihasilkan perusahaan.

Current Ratio. Current ratio adalah alat yang berguna sebagai pengukuran perusahaan ketika menunaikan utang jangka pendek atau hutang yang jatuh temponya akan ditagih secara menyeluruh atau dapat diartikan sebanyak apa asset yang ada untuk menutup utang jangka pendeknya yang akan jatuh tempo. Aset tersebut berupa aktiva lancar yang di dalamnya terdapat pinjaman yang diberikan, pendapatan yang masih diterima, biaya bayak dimuka, persediaan, piutang, surat-surat berharga, bank, dan kas (Zaman, 2021). Hutang lancar merupakan kewajiban jangka pendek perusahaan dalam jangaka waktu minimal satu tahun dimana hutang tersebut harus di lunasi dalam waktu setahun. Komponen hutang lancar meliputi biaya diterima di muka, hutang pajak, hutang gaji, hutang wesel, hutang deviden, hutang bank setahun, hutang dagang, dan hutang jangka pendek lain. Jika nilai CR 
rendah, bisa diungkapkan bahwasanya perusahaan kekurangan modal untuk melunasi hutangnya. Akan tetapi jika hasil ukuran rasio tinggi, dapat diungkapkan kondisi perusahaan sedang kurang baik, dikarenakan hal tersebut biasanya menunjukan kas dan keuangan perusahaan yang tidak di manajemenkan secara efektif.

Penelitian yang dilakukan (Sundas dan Butt, 2021) menjelaskan bahwa ada pengaruh positif signifikan current ratio terhadap ROA dan ROE. Penelitian tersebut sejalan dengan hasil riset dari (Chowdhury et al., 2018) menegaskan bahwasanya current ratio memiliki hubungan positif signifikan dengan ROA. Hal ini tersebut memperlihatkan bahwa perusahaan memiliki persediaan serta kapasitas yang efektif dalam kewajiban jangka pendek sehingga dikatakan perusahaan mampu membayarkan kewajiban hutang.

Hasil riset dari (Hasnell et al., 2018) menegaskan bahwasanya CR berpengaruh positif signifikan terhadap ROE. Sesuai dengan penelitian yang dilakukan oleh (Madushanka dan Jathurika, 2018) yang membuktikan bahwa terdapat pengaruh positif signifikan CR terhadap ROE. Artinya, peningkatan pada current ratio sejalan dengan peningkatan yang terjadi pada ROE. Hal ini membuktikan bahwa perusahaan mengalami peningkatan yang melebihi target profit dan semakin tinggi hasil current ratio maka dapat dikatakan semakin tinggi kemampuan likuiditas perusahaan. Apabila tingkat likuiditas mengalami kenaikan sehingga profit juga dapat menurun sebab perubahan nilai aset lancar yang terus mengalami peningkatan yang dapat berpengaruh juga dalam peningkatan hutang lancar perusahaan.

\section{Hipotesis}

Hipotesis yang digunakan pada penelitian ini yaitu berikut ini:

H1: Ada pengaruh signifikan positif antara acid ratio terhadap kinerja perusahaan.

$\mathrm{H} 2$ : Ada pengaruh signifikan positif antara current ratio terhadap kinerja perusahaan.

H3: Ada pengaruh signifikan positif antara sales growth terhadap kinerja perusahaan.

H4: Ada pengaruh signifikan positif antara firm size terhadap kinerja perusahaan. 


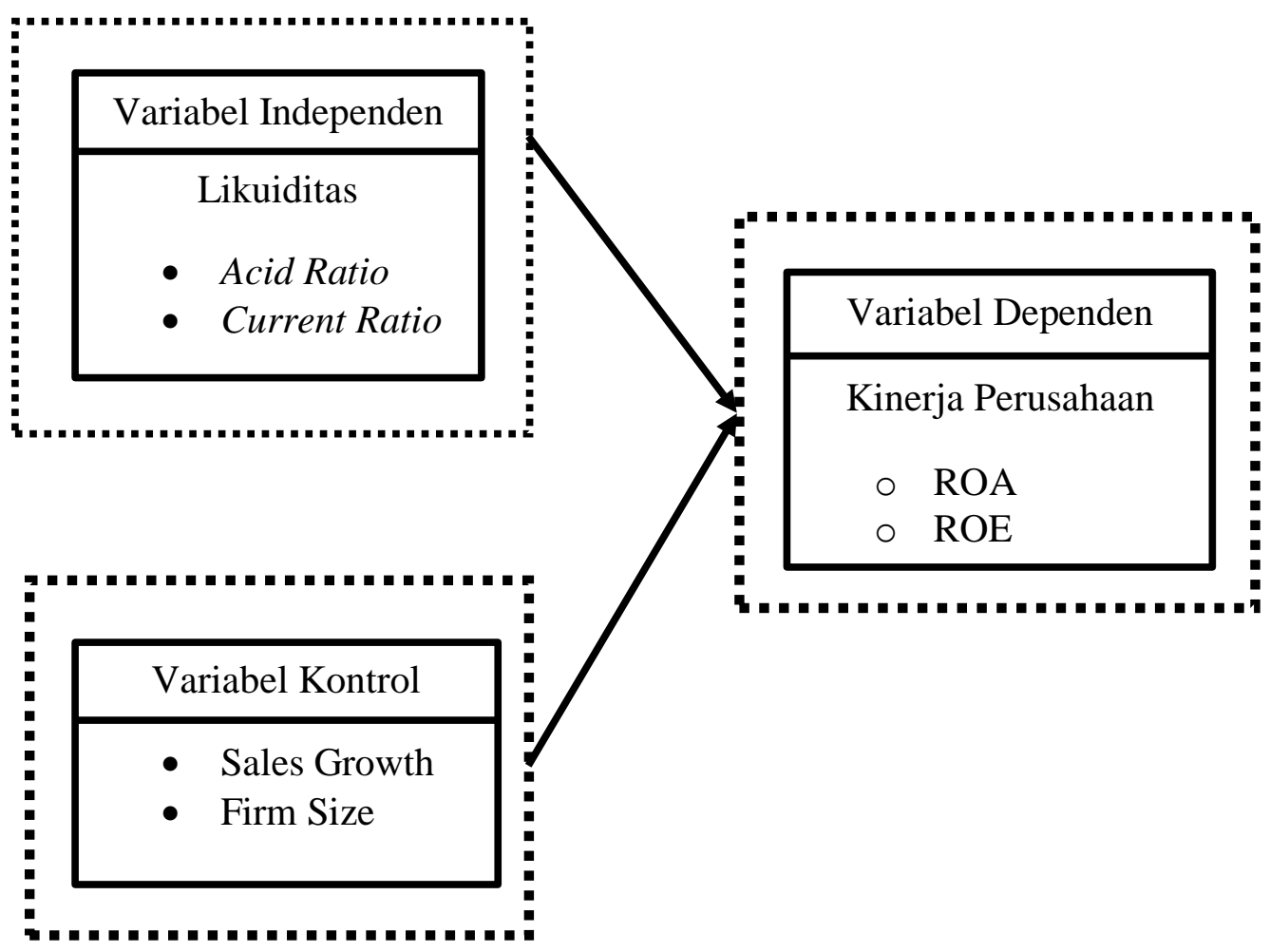

Gambar 1. Model Penelitian

\section{METODOLOGI}

Peneliti memanfaatkan jenis penelitian kuantitatif. Penelitian ini tujuannya sebagai pengujian hipotesis yang berupa pengaruh likuiditas terhadap kinerja perusahaan dari pertumbuhan penjualan dan ukuran perusahaan selaku variabel kontrol. Data yang dimanfaatkan oleh peneliti yaitu data sekunder yang didapat dari website resmi BEI (www.idx.co.id). Time horizon yang dipakai oleh peneliti berupa data panel karena penelitian ini menganalisa perusahaan subsektor minuman dan makanan yang tercatat di BEI sepanjang pengamatan 2016-2020. Metode analisis yang dipakai oleh peneliti yakni regresi data panel yang diolah memanfaatkan software e-views 12. Data penelitian ini diperoleh dari publikasi website BEI (idx.co.id).

Teknik pengambilan sampel ini menerapkan purposive sampling dimana kriteria keputusannya yakni berikut ini: (1) Perusahaan subsektor makanan dan minuman yang tercatat di BEI selama 2016-2020. (2) Perusahaan subsektor makanan dan minuman memiliki data yang dibutuhkan selaras dengan variabel penelitian. (3) Perusahaan yang bersangkutan tidak mengalami delisting selama 5 tahun terakhir 
Table 1. Pengukuran Variabel

\begin{tabular}{|c|c|c|c|}
\hline $\begin{array}{c}\text { Jenis } \\
\text { Variabel }\end{array}$ & Nama Variabel & Pengukuran & Referensi \\
\hline \multirow[t]{2}{*}{$\begin{array}{l}\text { Variabel } \\
\text { Dependen }\end{array}$} & Acid Ratio & $\frac{\text { Current assets - Inventories }}{\text { Current Liabilities }}$ & $\begin{array}{l}\text { (Sundas dan Butt, } \\
\text { 2021) }\end{array}$ \\
\hline & Current Ratio & \begin{tabular}{|c|} 
Current assets \\
\cline { 2 - 2 } Current Liabilities
\end{tabular} & $\begin{array}{l}\text { (Sundas dan Butt, } \\
\text { 2021) }\end{array}$ \\
\hline \multirow[t]{2}{*}{$\begin{array}{l}\text { Variabel } \\
\text { Independen }\end{array}$} & $R O A$ & \begin{tabular}{|c|} 
Net Profit Before Tax \\
Total Assets
\end{tabular} & $\begin{array}{l}\text { (Sundas dan Butt, } \\
\text { 2021) }\end{array}$ \\
\hline & $R O E$ & \begin{tabular}{|l|} 
Net Profit Before Tax \\
Shareholder's Equity
\end{tabular} & $\begin{array}{l}\text { (Sundas dan Butt, } \\
\text { 2021) }\end{array}$ \\
\hline \multirow[t]{2}{*}{$\begin{array}{l}\text { Variabel } \\
\text { Kontrol }\end{array}$} & Firm Size & Log of Sales & $\begin{array}{l}\text { (Sundas dan Butt, } \\
\text { 2021) }\end{array}$ \\
\hline & Sales Growth & \begin{tabular}{|c|} 
Net Sales \\
Net Fixed Assets
\end{tabular} & $\begin{array}{l}\text { (Sundas dan Butt, } \\
\text { 2021) }\end{array}$ \\
\hline
\end{tabular}

\section{HASIL DAN PEMBAHASAN}

Chow Test. Chow test merupakan uji yang berguna untuk menentukan model apakah yang lebih cocok dipakai penelitian ini, yakni common effect ataupun fixed effect. Uji chow test yang berdasarkan dari hipotesa nol tidak memiliki heterogenitas individu sedangkan dalam hipotesis alternative ada heterogenitas dalam cross section.

Tabel 2. Hasil Uji Chow

\begin{tabular}{c|c|c|c}
\hline Dependen & Chi-square & Prob & Keputusan \\
\hline ROA & 43.190916 & 0.0000 & Ditolak $\mathrm{H}_{0}$, Fixed Effect terpilih \\
\hline ROE & 37.016822 & 0.0000 & Ditolak $\mathrm{H}_{0}$, Fixed Effect terpilih \\
\hline
\end{tabular}

Sumber : Output regresi data panel E-views 12

Mengacu tabel hasil pengujian chow test, hasil mengungkapkan bahwasanya model 1 ( $\mathrm{Y}=\mathrm{ROA}$ ) sebanyak $0.0000<0.05$ dari nilai probabilitas cross section Chi-square, sehingga dihasilkan suatu keputusan yakni ada penolakan $\mathrm{H}_{0}$ maka model yang dipakai ialah FEM. Selain itu hasil menunjukkan bahwa model 2 (Y=ROE) sebanyak $0.0000<0.05$ dari nilai probabilitas cross section Chi-square, sehingga dihasilkan suatu keputusan yakni ada penolakan $\mathrm{H}_{0}$ maka model yang dipakai ialah FEM.

\section{Hausman Test}

Tabel 3. Hasil Uji Hausman Test

\begin{tabular}{c|c|c|c}
\hline Dependen & Chi-square & Prob & Keputusan \\
\hline ROA & 3.737828 & 0.9466 & Diterima $\mathrm{H}_{0}$, Random Effect terpilih \\
\hline ROE & 1.900975 & 0.7540 & Diterima $\mathrm{H}_{0}$, Random Effect terpilih \\
\hline
\end{tabular}

Sumber: Output regresi data panel E-views 12 
Mengacu table hasil pengujian hausman test, hasil model 1 menemukan bahwa sebesar $0.9466>0.05$ dari nilai probabilita cross-section Statistic, sehingga dihasilkan suatu keputusan yakni ada penerimaan $\mathrm{H}_{0}$. Maka model yang dipakai ialah REM. Selain itu, hasil model 2 menemukan bahwa sebanyak $0.7540>0.05$ dari nilai probabilitas cross-section Statistic, sehingga dihasilkan suatu keputusan yakni ada penolakan $\mathrm{H}_{0}$ maka model yang dipakai ialah REM.

Uji F. Berdasarkan hasil uji model 1, diperlihatkan bahwa nilai sebesar $0.000000<0.05$ dari nilai probabilita F-statistic. Maka hasil analisis penelitian ini mengungkapkan bahwa secara serempak variabel bebas yakni acid ratio, quick ratio, firm size, dan sales growth memberi pengaruh pada ROA maka model regresi layak dipakai pada penelitian ini.

Berdasarkan hasil pengujian model 2, diperlihatkan sebesar $0.000000<0.05$ dari nilai probabilita F-statistic. Maka hasil analisis penelitian ini mengungkapkan bahwa secara serempak variabel bebas yakni acid ratio, quick ratio, firm size, serta sales growth memberi pengaruh kepada ROE, sehingga ada kelayakan model regresi yang dipakai pada penelitian ini.

Uji Goodness of Fit (Uji Adjusted $\mathbf{R}^{\mathbf{2}}$ ). Mengacu hasil pengujian goodness of fit dalam model 1, didapat sebesar 0.740640 dari nilai adjusted $r$-square. Didapatkan variabel bebas yaitu acid ratio, quick ratio, firm size, dan sales growth sanggup menerangkan sebesar $74.0640 \%$ dari variasi dari ROA serta tersisa $25.9360 \%$ menerangkan bahwasanya ROA mendapat pengaruh dari faktor lain. Selain itu, hasil uji goodness of fit dalam model 2, didapat sebesar 0.781541 dari nilai adjusted r-square. Hal tersebut didapatkan variabel bebas yakni acid ratio, quick ratio, firm size, dan sales growth sanggup menerangkan bahwa sebesar $78.1541 \%$ dari variasi nilai ROE dan tersisa $21.8459 \%$ menerangkan bahwasanya ROE mendapat pengaruh dari faktor lain. Maka ada pengaruh kuat antara variabel bebas yaitu acid ratio, quick ratio, firm size, serta sales growth terhadap ROA dan ROE.

Metode Analisis Data. Model regresi data panel merupakan model yang dapat dipakai guna melihat hubungan dari variabel bebas dan kontrol pada variabel terikat. Berikut model regresi yang dipakai penelitian ini yaitu:

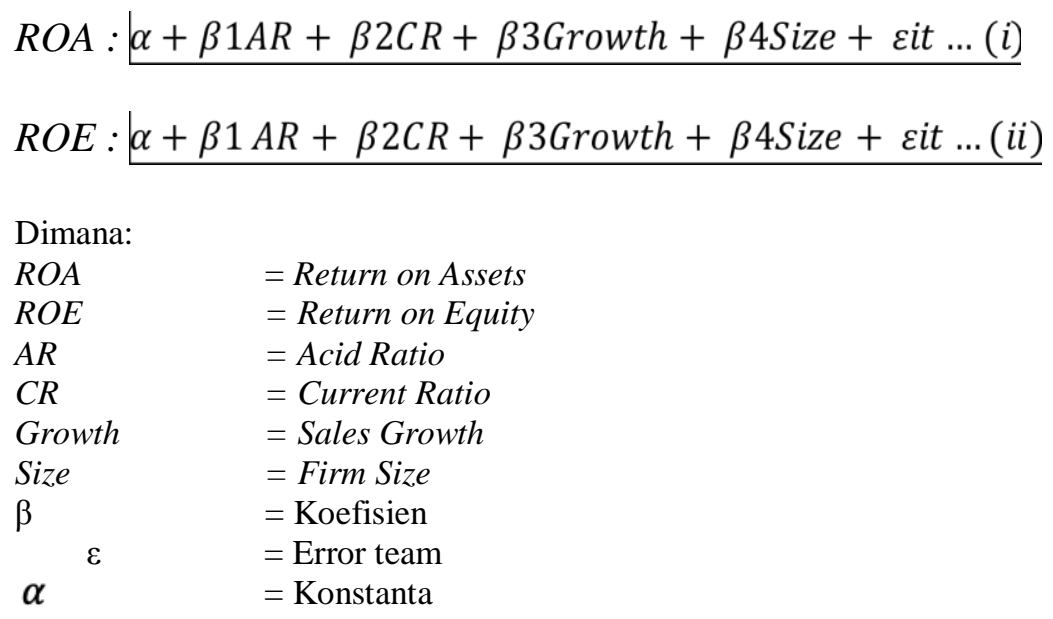


Tabel 5. Statistik Deskriptif

\begin{tabular}{l|c|c|c|c|c}
\hline \multicolumn{1}{c|}{ Variabel } & N & Mean & Maximum & Minimum & Std. Dev \\
\hline ROA & 31 & 0.069336 & 0.730100 & -2.628900 & 0.284036 \\
\hline ROE & 31 & 0.216777 & 2.600500 & -1.392300 & 0.558220 \\
\hline Acid Ratio & 31 & 1.277157 & 5.058000 & -0.578100 & 1.112906 \\
\hline Current Ratio & 31 & 1.882932 & 6.772000 & 0.098600 & 1.429387 \\
\hline Size & 31 & 29.00924 & 32.03450 & 25.64410 & 1.495736 \\
\hline Growth & 31 & 1.903532 & 12.77730 & 0.114400 & 1.973068 \\
\hline
\end{tabular}

Sumber: Output regresi data panel E-views 12

Analisis Regresi Data Panel. Metode analisis ini tujuannya sebagai pengujian pengaruh antara variabel bebas serta kontrol hterhadap variabel tergantung. Adapun hasil persaman regresi dari penelitian ini:

$R O A=-1,311034+0,063012 A R-0,039011 C R+0,023399$ Growth + 0,045806 Size (3) $R O E=-3,106644+0,157587 A R-0.178918 C R+0.042988$ Growth +0.116419 Size(4)

Uji T. Uji T ini berguna sebagai pengujian pengaruh antara setiap variabel bebas dan kontrol terhadap variabel tergantung. Berikut adalah tabel yang akan menyajikan hasil uji t dari setiap variabel pada penelitian ini:

Tabel 6. Hasil Uji T Regresi

\begin{tabular}{c|c|c|c}
\hline \multirow{2}{*}{$\begin{array}{c}\text { Variabel } \\
\text { Independen }\end{array}$} & \multicolumn{3}{|c}{ Variabel Dependen } \\
\cline { 2 - 4 } & Koefisien & Probabilitas & Kesimpulan \\
\hline Konstanta & -1.311034 & - & - \\
\hline AR & 0.063012 & 0.3680 & Tidak Signifikan \\
\hline CR & -0.039011 & 0.4842 & Tidak Signifikan \\
\hline SIZE & 0.045806 & 0.0097 & Positif Signifikan \\
\hline GROWTH & 0.023399 & 0.0196 & Positif Signifikan \\
\hline
\end{tabular}

Sumber: Output regresi data panel E-views 12

Acid Ratio (AR) sebesar $0.3680>0,05$ (alpha 5\%) dari nilai probabilitas yang memperlihatkan tidak adanya pengaruh. Hasil analisis ini memberikan kesimpulan bahwasanya tidak terdapat pengaruh antara Acid Ratio pada ROA.

Current Ratio (CR) sebanyak $0.4842>0,05$ (alpha 5\%) dari nilai probabilitas yang memperlihatkan tidak ada pengaruh. Hasil analisis ini memberikan kesimpulan bahwasanya tidak terdapat pengaruh signifikan antara Current ratio pada $R O A$.

Firm Size (SIZE) sebesar $0.0097<0,05$ (alpha 5\%) dari nilai probabilitas yang memperlihatkan adanya pengaruh signfikan. Besarnya koefisien adalah 0.045806. Hasil analisis ini menyimpulkan ada pengaruh signifikan positif antara Firm Size pada ROA. 
Sales Growth (GROWTH) memiliki nilai probabilitas sebesar $0.0196<0,05$ (alpha 5\%) yang menunjukan adanya pengaruh signfikan. Besarnya koefisien adalah 0.023399. Hasil penelitian ini memberikan kesimpulan terdapat pengaruh positif signifikan antara Sales growth terhadap ROA.

Tabel 7. Hasil Uji T Regresi

\begin{tabular}{c|c|c|c}
\hline \multirow{2}{*}{$\begin{array}{c}\text { Variabel } \\
\text { Independen }\end{array}$} & \multicolumn{3}{|c}{ Variabel Dependen } \\
\cline { 2 - 4 } & Koefisien & Probabilitas & Kesimpulan \\
\cline { 2 - 4 } Konstanta & -3.106644 & - & - \\
\hline AR & 0.157587 & 0.2690 & Tidak Signifikan \\
\hline CR & -0.178918 & 0.0000 & Positif Signifikan \\
\hline SIZE & 0.116419 & 0.0113 & Tidak Signifikan \\
\hline GROWTH & 0.042988 & 0.1276 &
\end{tabular}

Sumber: Output regresi data panel E-views 12

Acid Ratio (AR) sebesar $0.2690<0,05$ (alpha 5\%) dari nilai probabilitas yang memperlihatkan tidak adanya pengaruh. Hasil analisis ini memberikan kesimpulan bahwasanya tidak terdapat pengaruh antara Acid Ratio pada ROE.

Current Ratio (CR) sebesar $0.0000<0,05$ (alpha 5\%) dari nilai probabilitas yang menunjukan adanya pengaruh signifikan. Besaran koefisien adalah -0.178918. Hasil analisis ini memberikan kesimpulan bahwasanya ada pengaruh negatif signifikan antara Current Ratio pada ROE.

Firm Size (SIZE) sebesar $0.0113<0,05$ (alpha 5\%) dari nilai probabilitas yang menunjukan adanya pengaruh signifikan. Besaran koefisien adalah 0.116419. Hasil analisis ini memberikan kesimpulan bahwasanya ada pengaruh positif signifikan antara Firm Size pada ROE.

Sales Growth (GROWTH) sebesar $0.1276>0,05$ (alpha 5\%) dari nilai probabilitas yang memperlihatkan tidak adanya pengaruh. Hasil analisis ini memberikan kesimpulan bahwasanya tidak terdapat pengaruh antara Sales growth pada ROE. 


\section{KESIMPULAN}

Penelitian ini tujuannya agar dapat melihat pengaruh acid ratio, current ratio, sales growth dan ukuran perusahaan terhadap variabel dependen kinerja perusahaan dari perusahaan subsektor minuman dan makanan yang tercatat di BEI pada tahun 2016-2020. Dari hasil penelitian dan pembahasan yang sudah dipaparkan diatas didapatkan kesimpulan yaitu: (1) Acid ratio memiliki pengaruh tidak signifikan pada ROA. (2) Acid Ratio memiliki pengaruh tidak signifikan terhadap ROE. (3) Current Ratio mempunyai pengaruh tidak signifikan terhadap ROA. (4) Current Ratio memiliki pengaruh signifikan negatif terhadap ROE. (5) Sales growth memberi pengaruh signifikan positif pada ROA. (6) Sales Growth memberi pengaruh tidak signifikan pada ROE. (7) Firm size memberi pengaruh signifikan positif pada ROA. (8) Firm size memberi pengaruh signifikan positif pada ROA. Mengacu hasil penelitian, simpulan serta keterbatasan terhadap penelitian ini diharapkan bahwa peneliti di masa mendatang bisa melakukan penelitian pada industri manufaktur secara keseluruhan dan perlu menambah variabel dependen seperti Tobin's $Q$ untuk melakukan analisis pengaruh variabel bebas terhadap variabel tergantung kinerja perusahaan lainnya.

\section{REFERENSI}

Aguilar-Fernández, M. E., dan Otegi-Olaso, J. R. (2018). Firm size and the business model for sustainable innovation. Sustainability (Switzerland), 10(12). https://doi.org/10.3390/su10124785.

Ajorsu, E. S., dan Bakpa, E. K. (2019). The Effect of Liquidity and Financial Leverage on Firm Performance : Evidence from Listed Manufacturing Firms on The Ghana Stock Exchange. 91-100. https://doi.org/10.7176/RJFA.

Alawi, S. (2019). Relationship Between Capital Requirement, Ownership Structure, And Financial Performance In Saudi Arabian Keyword s. 9(9), 1077-1090. https://doi.org/10.18488/journal.aefr.2019.99.1077.1090.

Chowdhury, A. Y., Alam, M. Z., Sultana, S., dan Hamid, K. (2018). Impact of Working Capital Management on Profitability: A Case Study on Pharmaceutical Companies of Bangladesh. 6(1). https://doi.org/10.18178/joebm.2018.6.1.546.

Corsi, C., Prencipe, A., dan Capriotti, A. (2019). Linking organizational innovation, firm growth and firm size. Management Research, 17(1), 24-49. https://doi.org/10.1108/MRJIAM-06-2017-0760.

Fávero, L. P. L., Serra, R. G., dos Santos, M. A., dan Brunaldi, E. (2018). Cross-classified multilevel determinants of firm's sales growth in Latin America. International Journal of Emerging Markets, 13(5), 902-924. https://doi.org/10.1108/IJoEM-02-2017-0065.

Gitman, L. J., dan Zutter, C. J. (2015). Principles of Managerial Finance FoUrTeenTh edITIon.

Hasnel1, P. A., Hardiyanto2, A. T., dan Ilmiyono3, A. F. (2018). Pengaruh Leverage Keuangan Dan Likuiditas Terhadap Profitabilitas Pada PT. Telekomunikasi Indonesia TBK Tahun 2011-2018.

Heryanto. (2018). Effect Of Liquidity And Profitability To Bank Stock Return In Indonesia Stock Exchange (IDX). 10(2), 131-145. 
Hirdinis, M. (2019). Capital structure and firm size on firm value moderated by profitability. International Journal of Economics and Business Administration, 7(1), 174-191. https://doi.org/10.35808/ijeba/204.

Jurnal, J., dan Mea, I. (2021). Company Profit Growth And Quick Ratio On Stock Price : An Evidence Of Oil And Gas Companies In Jimea | Jurnal Ilmiah MEA (Manajemen, Ekonomi, dan Akuntansi ). 5(3), 848-856.

Kusjono, G., dan Rohman, M. A. A. (2020). Pengaruh Quick Ratio Dan Working Capital Turnover Terhadap Return On Equity ( Roe ) Pada PT Gudang Garam Tbk Tahun 2012-2018.

Sundas dan Butt, S. S. (2021). Impact Of Liquidity On Profitability And Performance. A Case Of Textile Sector Of Pakistan. 7(1), 122-129.

Mohamad Baktiar1), E. A., dan Zul Azhar3). (2019). Pengaruh Debt To Equity Ratio (Der), Net Profit Margin (Npm), Return On Equity (ROE), Return On Asset (ROA), Quick Ratio (QR), Dan Earning Per Share (EPS) Terhadap Harga Saham Pada Perusahaan Sub Sektor Industri Kimia Yang Terdaftar Di Bursa Efek Indonesi. 1-19.

Nguyen, V. H., Thu, T., Nguyen, C., Nguyen, V. T., and Do, D. T. (2021). Internal Factors Affecting Firm Performance: A Case Study in Vietnam. 8(5), 303-314. https://doi.org/10.13106/jafeb.2021.vol8.no5.0303.

Ning Tias, U. P., Purwanti, A., dan Surtikanti, S. (2020). Pengaruh Likuiditas (Quick Ratio) Dan Perputaran Modal Kerja Terhadap Return On Asset (Studi Kasus pada Perusahaan Sub Sektor Logam yang Terdaftar di Bursa Efek Indonesia Periode 20112015). Responsive, 3(1), 1. https://doi.org/10.24198/responsive.v3i1.28915.

Notoatmojo, M. I. (2018). Analisis Dampak Likuiditas Terhadap Profitabilitas Pada Bank Umum Syariah di Indonesia Periode 2010 -2016. 6, 19-41.

Nurdiana, D. (2018). Pengaruh Ukuran Perusahaan Dan Likuiditas Terhadap Profitabilitas. XII(6), 77-88.

Oyelade, A. (2019). The Impact Of Firm Size On Firms Performance In Nigeria : A Comparative Study Of Selected Firms In The Building Industry IN. January. https://doi.org/10.18488/journal.107.2019.71.1.9.

PATTIRUHU, J. R., dan PAAIS, M. (2020). Effect of Liquidity, Profitability, Leverage, and Firm Size on Dividend Policy. Journal of Asian Finance, Economics and Business, 7(10), 35-42. https://doi.org/10.13106/jafeb.2020.vol7.no10.035.

Prabowo, R. (2019). Analisis Pengaruh Struktur Modal, dan Likuiditas terhadap Profitabilitas pada Perusahaan Sektor Otomotif di indonesia. 10(1), 1-11.

Priatna, H., dan Yuliani, N. L. (2018). Pengaruh Perputaran Aktiva Tetap Dan Perputaran Piutang Terhadap Profitabilitas Studi Kasus Pada Koperasi Konsumen (KOPMEN) Bina Sejahtera Periode 2009 - 2016. 9k(25), 1-26.

Şamilloğlu, F., Öztop, A. O., dan Kahraman, Y. E. (2017). The Determinants of Firm Financial Performance : Evidence From Istanbul Stock Exchange (BIST). 8(6), 6267. https://doi.org/10.9790/5933-0806016267.

Samo, A. H., dan Murad, H. (2019). Impact of liquidity and fi nancial leverage on fi rm ' s pro fi tability - an empirical analysis of the textile industry of Pakistan. 23(4), 291305. https://doi.org/10.1108/RJTA-09-2018-0055.

Seissian, L. A., Gharios, R. T., dan Awad, A. B. (2018). ScienceDirect Structural and 
market-related factors impacting profitability: A cross sectional study of listed companiesa. AEBJ, 13(2), 125-133. https://doi.org/10.1016/j.aebj.2018.09.001.

Shakatreh, M. (2021). Mamoun Shakatreh. 7, 1131-1138. https://doi.org/10.5267/j.ac.2021.2.026.

Silvia, D., Sari, M. S., Akuntansi, A., dan Lampung, A. M. M. (2018). Pada PT . Mustika Ratu, Tbk. 203-210.

Surjandar, D. A. (2020). Asset, Capital Structure, Liquidity, Firm Size' S Impact On Stock Return International International of Commerce of Commerce and and Finance Finance Keywords : Asset 2 . 1 Agency Theory. 6(2), 81-91.

Ye, Y., Yeung, A. C. L., and Huo, B. (2020). Maintaining stability while boosting growth? The long-term impact of environmental accreditations on firms' financial risk and sales growth. International Journal of Operations and Production Management, 40(12), 1829-1856. https://doi.org/10.1108/IJOPM-05-2019-0407.

Zaman, M. B. (2021). Influence of Debt To Total Asset Ratio (DAR) Current Ratio (CR) and Total Asset Turnover (TATO) on Return On Asset (ROA) and Its Impact on Stock Prices on Mining Companies on the Indonesia Stock Exchange in 2008-2017. Journal of Industrial Engineering dan Management Research, 2(1), 114-132. https://jiemar.org/index.php/jiemar/article/view/119/95. 